\title{
Morphoanatomic aspects and phytochemical screening of Plinia edulis (Vell.) Sobral (Myrtaceae)
}

\author{
Tati Ishikawa ${ }^{1}$, Edna Tomiko Myiake Kato ${ }^{1 *}$, Massayoshi Yoshida ${ }^{2,3}$, Telma Mary Kaneko ${ }^{1}$ \\ ${ }^{1}$ Departamento de Farmácia, Faculdade de Ciências Farmacêuticas, Universidade de São Paulo, ${ }^{2}$ Departamento de \\ Química Fundamental, Instituto de Química, Universidade de São Paulo, ${ }^{3}$ Central Analítica, Centro de \\ Biotecnologia da Amazônia
}

*Correspondence:

E. T. M. Kato

Departamento de Farmácia

Faculdade de Ciências Farmacêuticas Universidade de São Paulo

Av. Prof. Lineu Prestes, 580

05508-900 São Paulo - SP, Brasil

E-mail: myiake@usp.br
Plinia edulis (Myrtaceae), popularly known as "cambucá", is a Brazilian medicinal plant employed in the treatment of stomach problems and throat affections by the "caiçaras", fishermen of coastal localities. Aiming to contribute with the species knowledge the leaves of $\mathrm{P}$. edulis were analyzed macro and microscopically and the chemical composition of the volatile oil was determined using a combination of GC/MS and retention indices. The antimicrobial assay and the phytochemical screening of the aqueous ethanol extract of the leaves have been performed to correlate the secondary metabolites and the traditional use. Leaves present morphological characteristics of others Myrtaceae species and some particularities, such as the circular idioblasts in number of 2 to 4, scattered perpendicularly at the adaxial surface, with druses or prismatic crystals. In the volatile oil fifteen components have been identified, of which epi- $\alpha$-cadinol (21.7\%), $\alpha$-cadinol $(20.2 \%)$ and trans-caryophyllene (14.2\%) were major. The phytochemical screening of the aqueous ethanol extract showed the presence of substances with pharmacological interest, such as flavonoids, tannins, saponins and terpenoids but, despite of the presence of these classes, the extract did not inhibit the growth of Aspergillus niger, Candida albicans, Escherichia coli and Staphylococcus aureus in a concentration of $1,000 \mathrm{mg} / \mathrm{mL}$.

\section{INTRODUCTION}

The family Myrtaceae native in tropical and subtropical regions comprises about 3.5 thousand species (Barroso, 1984). Some Myrtaceae had been proven to be effective to inhibit the growth of microorganisms (Chaieb et al., 2007; Ndounga et al., 1994; Anesini, Perez, 1993). The genus Plinia L. comprises about 30 species from Costa

\section{Uniterms}

- Plinia edulis (Vell.) Sobral

- Myrtaceae

- Medicinal plants
Rica to southern South America and in the West Indies (Landrum, Kawasaki, 1997). These species have been subject of chemical and biological studies. Some species accumulate flavonoids (Mendez et al., 1997; 1994) which have been evaluated as inhibitors of the enzyme xanthineoxidase (Theoduloz et al., 1988). Apel et al. (2006) analyzing the volatile oil of four Plinia species verified predominance of sesquiterpenes in their. 
Plinia edulis (Vell.) Sobral is a tree, which attains 5$10 \mathrm{~m}$ high, growing in Brazil from Rio de Janeiro to Santa Catarina States (Lorenzi et al., 2006). It is endemic to the Atlantic rainforest and popularly designated as "cambucá" (Lorenzi et al., 2006). It is well known due their juicy fruits and uses in folk medicine against stomach problems and throat affection (Nascente, 2008; Maciel, Cardoso, 2003). Although the species has been commonly used in traditional medicine, scientific reports on it are limited. This plant has been shown to exhibited gastroprotective activity (Ishikawa et al., 2003).

Despite its therapeutic activity there are not studies concerning morphoanatomical and phytochemical characterization to distinguish this starting plant material from adulterants. So, the leaves of $P$. edulis were described macro and microscopically. In order to rationalize relationship between chemical constituents and traditional use of the medicinal plant, the composition of the volatile oil from leaves was determined, as well as the phytochemical analysis and evaluation for antimicrobial effect of leaves aqueous ethanol extract.

\section{MATERIAL AND METHODS}

\section{Plant material}

The leaves of $P$. edulis were collected during flowering at morning period in Trindade, Paraty City, Rio de Janeiro State, Brazil. Flowering material was identified and a voucher specimen has been deposited in the Instituto de Botânica de São Paulo, under number SP 356.472.

\section{Macro and microscopical analysis}

The crude drug consisting of dried leaves of $P$. edulis was analyzed for its dimension, form, color, surface and organoleptic characteristics. The material was observed by aid of a stereomicroscope Willd.

Fresh vegetable material or fixed in FAA 70 (formalin, acetic acid and 70\% ethanol) and maintained in $70 \%$ ethanol solution (Berlyn, Miksche, 1976) was used for anatomical analysis. Transverse sections were made at the middle part of the midrib of leaves and at the mid-region of the petiole. Sections were then cleared in bleach, washed and stained in $0.1 \%$ safranin in $50 \%$ ethanol and astra blue (Roeser, 1962). Cuticular macerations and dissociation of the stem were made. The material used was left overnight in equal volumes of $20 \%$ hydrogen peroxide and glacial acetic acid at $60^{\circ} \mathrm{C}$ (Franklin, 1945). The material obtained was stained in safranin/astra blue solution.

The results were registered with aid of photo- microscope Nikon, Optiphot. Scales were obtained in the same optical conditions.

\section{Volatile oil}

Fresh leaves (700 g) were submitted to hydrodistillation during $4 \mathrm{~h}$ in a Clevenger-type apparatus.

\section{Volatile oil analysis}

The leaf oil was analyzed by GC/MS in a Shimadzu, QP-5000 GC/MS instrument under the following conditions: dimethylpolysiloxane B-5 fused silica capillary column ( $30 \mathrm{~m} \times 0.25 \mathrm{~mm}$; film thickness $0.25 \mathrm{~mm})$; carrier gas $\mathrm{He}(1 \mathrm{~mL} / \mathrm{min})$; injector temperature $240^{\circ} \mathrm{C}$; detector temperature $230{ }^{\circ} \mathrm{C}$; column temperature $60-240{ }^{\circ} \mathrm{C}$ at $3{ }^{\circ} \mathrm{C} / \mathrm{min}$; mass spectra electron impact $70 \mathrm{eV}$. The identification of the constituents was performed by computer library search (Nist 62 library), retention indices (Adams, 1995) and interpretation of the mass spectra (McLafferty and Stauffer, 1989).

\section{Preparation of the freeze-dried extract}

The plant material was dried at $40-45^{\circ} \mathrm{C}$ in oven with air circulation. The dried leaves were grounded and percolated with $70 \%$ ethanol at room temperature (Farmacopéia, 1988). The solution was concentrated at $40{ }^{\circ} \mathrm{C}$ under low pressure and the residue was freeze-dried.

\section{Phytochemical screening}

The freeze-dried extract was assayed for the occurrence of flavonoids, saponins and tannins using TLC methods (Wagner, Bladt, 1996).

\section{Antimicrobial activity}

Antimicrobial activity was evaluated against Gram positive bacteria Staphylococcus aureus (ATCC 6538); Gram negative bacteria Escherichia coli (ATCC 8739) and the fungi Candida albicans (ATCC 10231) and Aspergillus niger (ATCC 16404). The minimum inhibitory concentration(MIC) was determined by the macrobroth dilution method (Wadt et al., 1996). The microorganisms suspensions were adjusted to the standard concentration of approximately $1.0 \times 10^{2} \mathrm{CFU} / \mathrm{mL}$. The test bacterial strains were inoculated into Difco ${ }^{\mathrm{TM}}$ Tryptic Soy Broth and the fungi into Difco ${ }^{\mathrm{TM}}$ Sabouraud Dextrose Broth. Each sample concentration was added with test microorganisms, in triplicates. At the same conditions, a solution of chloranfenicol $(5 \mu \mathrm{g} / \mathrm{mL})$ was added with test 
bacteria and anfotericin $\mathrm{B}(1 \mu \mathrm{g} / \mathrm{mL})$ with test fungi (positive controls), while the solvent was used as negative control. Tubes were incubated at $35-37^{\circ} \mathrm{C}$ for $24 \mathrm{~h}$ (bacteria) and 20 $25^{\circ} \mathrm{C}$ for $48 \mathrm{~h}$ (C. albicans) or 5 days (A. niger). The MIC was as taken as the lowest concentration showing no noticeable growth (turbidity).

\section{RESULTS AND DISCUSSION}

In general, the macro and microscopical analysis of $P$. edulis evidenced typical features of Myrtaceae (Metcalfe, Chalk, 1950; Landrum, Kawasaki, 1997), but some anatomical features are peculiars in this species. Secretory cavities, bicollateral vascular bundles and crystalliferous cells have been mentioned as being widespread in Myrtaceae (Metcalfe, Chalk, 1950). There are few comparable studies on the botanical aspects of Plinia (Landrum, Kawasaki, 1997; Kawasaki, Holst, 2002).

The macroscopical analysis showed that the leaves of P. edulis are simple, lanceolate to oblong-lanceolate with entire margins (Figure 1A). The apex is acute to acuminate and the base is cuneate to obtuse. The foliar lamina has from 14 to $17 \mathrm{~cm}$ in lenght, from 4 to $6 \mathrm{~cm}$ in width and translucent glands. The venation is pinnate and brochidodromous. The lateral veins anastomosing about 1$3 \mathrm{~mm}$ from margin form an inframarginal vein. Leaf venation pattern seems to combine characteristics of other Plinia species (Kawasaki, Holst, 1994; 2002). Non-glandular trichomes cover the whole leaf surface but they are more abundant on the abaxial surface and along the veins. The lamina is chartaceous, brownish-green and brittle. The cylindrical petiole has from 1.5 to $2.5 \mathrm{~cm}$ in lenght. The leaves have aromatic odor and astringent taste.

In frontal view, the epidermis is composed of polygonal cells with slightly undulate anticlinal walls. In transverse section, the unilayered epidermis presents quadrangular cells (Figures 1B and 1C). Secretory cavities are more frequent beneath the epidermis (figure 1B), although they are distributed throughout the lamina. The pattern of development of these cavities was not studied here. In surface view, distinct cells in pairs can be seen over the secretory cavities. These cells differ from the other epidermal cells in form, size and the dividing wall is sinuous. The mesophyll is dorsiventral with one layer of palisade parenchyma that comprises about $1 / 5$ of the mesophyll width. The spongy parenchyma has conspicuous air spaces. Large idioblasts, in number of two to four, with druses and prismatic crystals of calcium oxalate are scattered perpendicularly at the adaxial face (Figure 1C). The leaves are hypostomatic, with anomocytic stomata predominantly (Figure 1D). The adaxial surface cells are comparatively bigger than the cells of the other face. The outer wall of adaxial and abaxial cells are thickly cutinized. Lignified, curved, non-glandular trichomes are present on both lamina surfaces, especially at the abaxial face of the midrib, where they are longer. These trichomes are unicellular, with acute apical cells (Figure 1E). This finding is in agreement with some authors (Landrum, Kawasaki, 1997; Kawasaki, Holst, 2002).

The transverse section of the midrib is nearly planeconvex. The vascular system forms an incomplete cylinder with incurved ends. The vascular bundles are bicollateral and fibers form a cylinder around the outer phloem (Figure 1F).

The petiole in transection is plane-convex or slightly concave-convex. The epidermal cells are anticlinally elongated and thickly cutinized. The vascular system is arranged in a broad crescent shape with deeply incurved

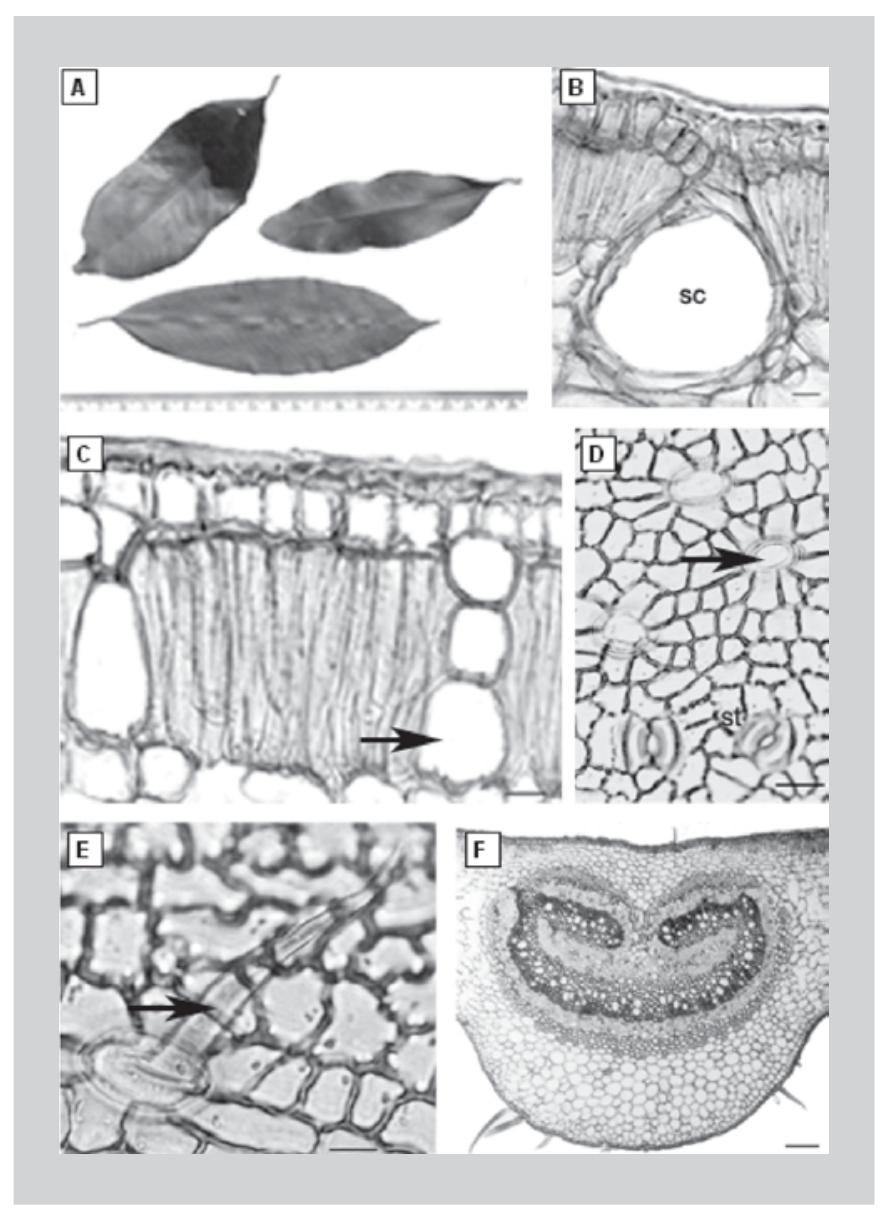

FIGURE 1 - Macro and microscopical analysis of leaves of Plinia edulis (Vell.) Sobral. A: crude drug. Transverse sections ( $\mathrm{B}, \mathrm{C}, \mathrm{F})$ and frontal view $(\mathrm{D}, \mathrm{E})$. B: secretory cavity (sc); C: idioblasts (arrow); D: stomata (st) and basis of trichomes (arrow); E: non-glandular trichome (arrow); F: midrib.

Bars: $10 \mu \mathrm{m}$ (B, E); $20 \mu \mathrm{m}$ (D); $40 \mu \mathrm{m}$ (C); $100 \mu \mathrm{m}$ (F). 
adaxial ends (Figure 2A). The indumentum is composed of the same type of non-glandular trichome, but compared to lamina, they are more abundant (Figure 2B). Druses and some prismatic crystals are present in the cortex (Figure 2C) but they are more numerous in the medullar region. Secretory cavities are frequent (Figure 2D). Phloem contains numerous prismatic crystals arranged in crystal series which are observed in the dissociated tissue (Figure 2E).

Various plant morphological features may affect the foraging efficacy of predatory insects or parasitoids. The effectiveness of the defense mechanisms in response to environmental conditions and predatory insects or parasitoids may include physical and chemical factors (Horgan et al., 2007). Non-glandular trichomes and calcium oxalate crystals may form physical obstacles to herbivores, whereas the secretory cavities and tanniferous cells may release chemical repellents. The lipophylic

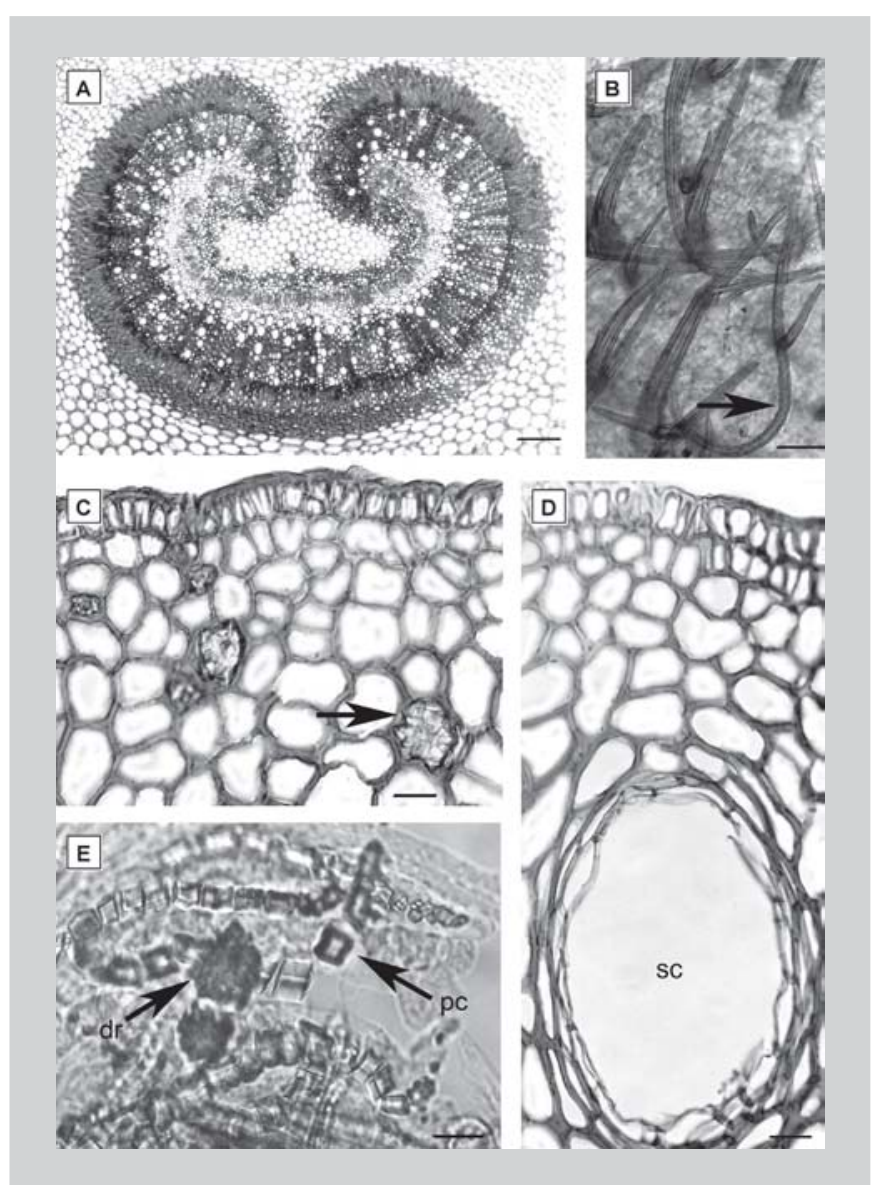

FIGURE 2 - Microscopical analysis of the petiole of Plinia edulis (Vell.) Sobral. Transverse sections (A, C, D) and dissociated tissue (B, E). A: vascular system; B: nonglandular trichomes; C: druses (arrow); D: secretory cavity (sc); E: druses (dr) and prismatic crystals (pc).

Bars $=20 \mu \mathrm{m}(\mathrm{C}, \mathrm{D}, \mathrm{E}) ; 40 \mu \mathrm{m}$ (B); $100 \mu \mathrm{m}$ (A). content of secretory cavities and phenolics have been demonstrated antimicrobial activity, repellent properties and sometimes represent a feeding barrier (Omolo et al., 2004; Harborne, 2001)

The morphoanatomical analysis has been proven to be a rapid and reliable method for quality control of the plant material used for medicinal purposes. Despite the overall similarity of structures with other Myrtaceae, the combination of lamina and midvein structure, together with series of two to four idioblasts scattered perpendicularly at the adaxial face may be a criterion for the analysis of this crude drug.

On the other hand, the presence of lipophilic content observed in the secretory cavities leads to the phytochemical analysis of the composition of the oil, which is summarized in Table I. The hydrodistillation yielded $0.02 \%$ of oil, which contains as major components the epi- $\alpha$-cadinol $(21.7 \%)$, the $\alpha$-cadinol (20.2\%) and the trans-caryophyllene (14.2\%). In this analysis, the oil composition was quite different from that described to specimen collected in Porto Alegre (South Brazil) (Apel et al., 2006), that showed as main components the $\beta$-caryophyllene and its oxide (39.3\%). Although the difference in composition could be due to distinct preparation procedure, geographical or seasonal variations, this finding could suggest alternatively the occurrence of chemotypes.

TABLE I - Percentage composition of the leaf oil of Plinia edulis (Vell.) Sobral

\begin{tabular}{lcc}
\hline Constituents & Retention Indices & Percentage \\
\hline 1,8-cineole & 1030 & 1.8 \\
trans-caryophyllene & 1419 & 14.2 \\
$\alpha$-humulene & 1453 & 4.5 \\
allo-aromadendrene & 1461 & 2.0 \\
$\alpha$-selinene & 1493 & 2.8 \\
$\alpha$-muurolene & 1499 & 2.1 \\
$\gamma$-cadinene & 1514 & 1.8 \\
$\delta$-cadinene & 1523 & 5.0 \\
spathulenol & 1576 & 1.2 \\
globulol & 1583 & 9.1 \\
khushimone & 1593 & 1.8 \\
1-epi-cubenol & 1628 & 2.6 \\
Epi- $\alpha$-cadinol & 1641 & 21.7 \\
$\alpha$-muurolol & 1646 & 4.0 \\
$\alpha$-cadinol & 1654 & 20.2 \\
\hline
\end{tabular}

The traditional use of $P$. edulis and the presence of flavonoids, tannins, and terpenoids evidenced by the preliminary phytochemical analysis lead us to search for antimicrobial activity of the extract. The antibacterial and antifungal activity of several plants have been attributed to terpenoids (Wyatt et al., 2005; Filipowics et al., 2003) and 
phenolics (Heinonen, 2007) such as tannin, responsible for the astringent taste of $P$. edulis leaves. Despite of the fact that these classes of compounds had shown antibiotic activity against some types of strains (Heinonen, 2007; Kim, Shin, 2004; Kubo, Muroi, Kubo, 1993), the leaf extract did not inhibit neither the growth of $A$. niger and $C$. albicans in a concentration of $2.000 \mathrm{mg} / \mathrm{mL}$ nor the growth of $E$. coli and $S$. aureus in a concentration of $1.000 \mathrm{mg} / \mathrm{mL}$. Further biological and phytochemical studies have been developing to verify the relationship of the pharmacological activity and chemical constituents of $P$. edulis.

\section{RESUMO}

\section{Aspectos morfoanatômicos e triagem fitoquímica de Plinia edulis (Vell.) Sobral (Myrtaceae)}

Plinia edulis (Myrtaceae), popularmente conhecida como "cambucá", é uma planta medicinal nativa do Brasil e empregada no tratamento de problemas estomacais e afecções de garganta por populações caiçaras. Buscando contribuir para o conhecimento da espécie, as folhas de P. edulis foram caracterizadas macro e microscopicamente e a composição química do óleo volátil foi determinada usando uma combinação de CG/EM e índices de retenção. O extrato hidroetanólico das folhas foi avaliado quanto ao perfil fitoquímico e à atividade antimicrobiana procurando-se a correlação dos metabólitos secundários e o uso tradicional. As folhas apresentam características morfológicas comuns a outras mirtáceas e algumas particularidades, como a presença de 2 a 4 idioblastos, contendo drusas e cristais prismáticos, dispostos perpendicularmente à face adaxial. No óleo volátil foram identificados 15 componentes, dentre os quais o epi- $\alpha$ cadinol (21.7\%), o $\alpha$-cadinol (20.2\%) e o transcariofileno (14.2\%) foram os majoritários. A triagem fitoquímica do extrato hidroetanólico evidenciou a presença de substâncias de interesse farmacológico, tais como flavonóides, taninos, saponinas e terpenóides. No entanto, apesar da presença destas classes, o extrato não inibiu o crescimento de Aspergillus niger, Candida albicans, Escherichia coli e Staphylococcus aureus na concentração de até $1.000 \mathrm{mg} / \mathrm{mL}$.

UNITERMOS: Plinia edulis (Vell.) Sobral. Myrtaceae. Planta medicinais.

\section{ACKNOWLEDGEMENTS}

The authors would like to thank Lúcia Rossi for botanical identification and CAPES, CNPq for fellowships and financial support.

\section{REFERENCES}

ADAMS, R.P. Identification of essential oil components by gas cromatography/ mass spectroscopy. Carol Stream: Allured Publishing Corporation, 1995. 469p.

ANESINI, C.; PEREZ, C. Screening of plants used in Argentine folk medicine for antimicrobial activity. $J$. Ethnopharmacol., v.39, p.119-128, 1993.

APEL, M.A.; SOBRAL, M.; ZUANAZZI, A.; HENRIQUES, A.T. Essential oil composition of four Plinia species (Myrtaceae). Flavour Fragr. J., v.21, p.565-567, 2006.

BARROSO, G.M. Sistemática de angiospermas do Brasil. Viçosa: Universidade Federal de Viçosa, 1984. 277p.

BERLYN, G.P.; MIKSCHE, J.P. Botanical microtechnique and cytochemistry. Ames: Iowa State University Press, 1976. $326 \mathrm{p}$.

CHAIEB, K.; HAJLAOUI, H.; ZMANTAR, T.; KAHLANAKBI, A.B.; ROUABHIA, M.; MAHDOUANI, K.; BAKHROUT, A. The chemical composition and biological activity of clove essential oil, Eugenia caryophyllata: a short review. Phytother. Res., v.21, p.501-506, 2007.

FARMACOPÉIA Brasileira. 4.ed. São Paulo: Atheneu, 1988. pt.1.

FILIPOWICZ, N.; KAMINSKI, M., KURLENDA, J.; ASZTEMBORSKA, M. OCHOCKA, J.R. Antibacterial and antifungical activity of juniper berry oil and its selected components. Phytother. Res., v.17, p.227-231, 2003.

FRANKLIN, G.L. Preparation of the thin sections of synthetic resins and wood-resin composites, and a new macerating method for wood. Nature, v.155, p.51, 1945.

HARBORNE, J.B. Twenty-five years of chemical ecology. Nat. Prod. Rep., v.18, p.361-379, 2001. 
HEINONEN, M. Antioxidant activity and antimicrobial effect of berry phenolics - a Finnish perspective. Mol. Nutr. Food Res., v. 51, p. 684-691, 2007.

HORGAN, F.G., QUIRING, D.T., LAGNAOUI, A., PELLETIER, Y. Variable responses of tuber moth to the leaf trichomes of wild potatoes. Entomol. Exp. Appl., v.125, p.1-12, 2007.

ISHIKAWA, T.; BACCHI, E.M.; KATO, E.T.M. Avaliação da toxicidade aguda e da atividade antiúlcera de Plinia edulis (Vell.) Sobral. Rev. Bras. Cienc. Farm., v.39, suppl.3, p.100, 2003.

KAWASAKI M.L., HOLST B.K. New species and a new combination in Myrtaceae from northeastern South America. Brittonia, v.46, n.2, p.137-143, 1994.

KAWASAKI M.L., HOLST B.K. Two new species of Plinia (Myrtaceae) from coastal forests of Brazil. Brittonia, v.54, n.2, p.94-98, 2002.

KIM, Y.S.; SHIN, D.H. Volatile constituents from the leaves of Callicarpa japonica Thunb. and their antibacterial activities. J. Agric. Food Chem., v.52, p.781-787, 2004.

KUBO, I.; MUROI, H.; KUBO, A. Antibacterial activity of long-chain alcohols against Streptococcus mutans. J. Agric. Food Chem., v.41, p.2447-2450, 1993.

LANDRUM, L.R.; KAWASAKI, M.L. The genera of Myrtaceae in Brazil: an illustrated synoptic treatment and identification keys. Brittonia, v.49, n.4, p.508-536, 1997.

LORENZI, H.; BACHER, L.; LACERDA, M.; SARTORI, S. Frutas brasileiras e exóticas cultivadas. São Paulo: Instituto Plantarum, 2006. p.640.

MACIEL, A.C., CARDOSO, N. Cura, sabor e magia nos quintais da Ilha Grande. Rio de Janeiro: EdUERJ, 2003. p.104.

McLAFFERTY, F.W.; STAUFFER, D.B. The Wiley/NBS registry of mass spectral data. New York: John Wiley, $1989.7 \mathrm{v}$.

MENDEZ, J.; HASEGAWA, M.; BILIA, A. N.; MORELLI, I. 5,7,2',5'-Tetrahydroxydihydroflavonol 3-rhamnoside from Plinia pinnata. Phytochemistry, v.36, p.1087-1088, 1994.
MENDEZ, J.; HASEGAWA, M.; MORELLI, I.; BILIA, A. N. A new triterpene from the twigs of Plinia pinnata. Fitoterapia, v.68, p.5, 1997.

METCALFE, C.R.; CHALK, L. Anatomy of the dicotyledons. Oxford: Clarendon Press, 1950. v.1. p.620631.

NASCENTE, A.S. Uso medicinal de frutos. In: BRASIL. Ministério da Agricultura, Pecuária e Abastecimento. EMBRAPA. Artigos técnicos. Avaible in: http:// www.cpafro.embrapa/Artigos/uso_medic.htm. Access : 01 mar 2008.

NDOUNGA, M.; BILALA, J.P.; OUABONZI, A. Antibacterial properties of aqueous extracts from Syzygium species. Fitoterapia, v.65, p.80-82, 1994.

OMOLO, M.O.; OKINYO, D.; NDIEGE, I.O.; LWANDE, W.; HASSANALI, A. Repellency of essential oils of some Kenyan plants against Anopheles gambiae. Phytochemistry, v.65, p.2797-2802, 2004.

ROESER, K.R. Die nadel der schwarzkiefer-massenprodukt und kunstwerk der natur. Mikrokosmos, v.61, p.33-36, 1962.

THEODULOZ, C.; FRANCO, L.; FERRO, E.; SCHMEDA-HIRSCHMANN, G. Xanthine oxidase inhibitory activity of Paraguaian Myrtaceae. $J$. Ethnopharmacol., v.24, p.179-183, 1988.

WADT, N.S.Y.; OHARA, M.T.; SAKUDA-KANEKO, T.M.; BACCHI, E.M. Ação antimicrobiana de Leonurus sibiricus L. Rev. Bras. Farmacogn., v.5, p.167-174, 1996.

WAGNER, H. M.; BLADT, S. Plant drug analysis. Berlin: Springer-Verlag, 1996. 384 p.

WYATT, R.M.; HODGES, L. D.; KALAFATIS, N., WRIGHT, P. F. A.; WYNNE, P. M.; MACRIDES, T. A. Phytochemical analysis and biological screening of leaf and twig extracts from Kunzea ericoides. Phytother. Res., v. 19, p. 963-970, 2005.

Recebido para publicação em 21 de setembro de 2007 Aceito para publicação em 07 de julho de 2008 